UDK 327:316.32

\title{
THE ROLE OF THE CIVIL SOCIETY IN GLOBAL CLIMATE CHALLENGES COMBATING
}

\section{РОЛЬ ГРОМАДЯНСЬКОГО СУСПІЛЬСТВА У ВИРІШЕННІ ГЛОБАЛЬНИХ КЛІМАТИЧНИХ ВИКЛИКІВ}

\section{РОЛЬ ГРАЖДАНСКОГО ОБЩЕСТВА В БОРЬБЕ С ГЛОБАЛЬНЫМИ ВЫЗОВАМИ КЛИМАТА}

\section{Shevchenko O. V.}

$\mathrm{PhD}$ (Politics), associate professor, associate professor of the Department of International Mediacommunication and Communication Technologies, Taras Shevchenko National University of Kyiv, Institute of International Relations, email: ovsh@ukr.net

\section{Шевченко О. В.}

к.політ.н., доцент, доцент кафедри міжнародних медіакомунікацій і комунікативних технологій Інституту міжнародних відносин Київського національного університету імені Тараса Шевченка, e-mail: ovsh@ukr.net

\section{Шевченко Е. В.}

к.полит.н., доцент, доцент кафедры международных медиакоммуникаций и коммуникативных технологий Інститута международных отношений Киевского национального университета имени Тараса Шевченко, e-mail: ovsh@ukr.net

Annotation. Humanity faces the challenge of identifying ways how to adapt and mitigate the effects of global climate change. A thorough analysis of all the adaptive capabilities and institutions involved in this process is required to meet this challenge. Climate change mitigation and adaptation is a cross-border, multi-level, multi-sectoral and multi-activity challenge with longrange, specific characteristics and many uncertainty parameters. Therefore, many different actors from different sectors are involved in regulating this process with their strategies and interests. There are several key players who play a special role. These include civil society institutions. The article analyzes the Ukrainian and international practice of involving civil society in solving global climate problems. It is shown that public organizations and movements, celebrities and individuals act as incubators and accelerators of new strategies to address climate challenges.

Keywords. Global climate change, adaptation, civil society, social movements, celebrities.

Анотація. Людство стикається з проблемою визначення шляхів адаптаџіï та пом'якшення наслідків глобальних кліматичних змін. Для вирішення иієї проблеми необхідний ретельний аналіз усіх адаптаційних можливостей та установ, що беруть участь у цьому процесі. Пом'якшення наслідків зміни клімату та адаптаџія до них є транскордонним, багаторівневим, багатогалузевим та багатопрофільним викликом з дальніми, специфічними характеристиками та багатьма параметрами невизначеності. Тому багато різних суб'єктів з різних секторів беруть участь у регулюванні иього процесу зі своїми стратегіями та інтересами. С кілька ключових гравців, які відіграють особливу роль. До них належать інститути громадянського суспільства. В статті проаналізовано украӥнську та міжнародну практику залучення громадянського суспільства до вирішення глобальних кліматичних проблем. Показано, щуо громадські організаџї та рухи, відомі особистості та окремі індивіди виступають як інкубатори і прискорювачі нових стратегій вирімення кліматичних викликів.

Ключові слова. Глобальні зміни клімату, адаптачія, громадянське суспільство, соиіальні рухи, знаменитості.

Аннотация. Человечество сталкивается с проблемой определения способов адаптации и смягчения последствий глобального изменения климата. Для решения этой задачи необходим тщательный анализ всех адаптивных возможностей и институтов, вовлеченных в этот процесс. Смягчение последствий изменения климата и адаптация к ним 
- это трансграничная, многоуровневая, многоотраслевая и многоотраслевая задача $c$ долгосрочными, специифическими характеристиками и множеством параметров неопределенности. Таким образом, в регулирование этого процесса вовлечено множество различных субъектов из разных секторов, исходя из своих стратегий и интересов. Есть несколько ключевых игроков, которые играют особую роль. К ним относятся институты гражданского общества. В статье проанализировано украинский и мировой опьыт вовлечения гражданского общества в решение глобальных климатических вызовов. Показано, что общественные организации и движения, известные личности и отдельные индивиды выступают как инкубаторы и ускорители новых стратегий решения климатических вызовов.

Ключевые слова. Глобальное изменение климата, адаптаџия, гражданское общество, общественные движения, знаменитости.

Introduction. Addressing Global Climate Change rise a number of topical issues. The key issue is to identify the participants in the climate change management process and the scope of their competencies and areas of responsibility. Practice shows that current global problems, which are related to global climate change, cannot be solved individually and straightforwardly without involving all stakeholders and the general public. Another pressing issue is the development of management mechanisms that would facilitate the implementation of adaptation strategies, mitigation and enhancement of adaptive capacity of society and planetary ecosystems, including such mandatory elements as problem definition and problem statement, defining synergies and coordination actions between the participants of the process, timing of tasks implementation, choice of tools and organization of scientific support. Climate change requires collective action at the global level; major changes must be initiated by the most influential international actors representing the largest emitters, economies and potential for influence.

UN Secretary-General Antonio Guterres called the problem of climate change "a major issue of our time, and its solution is a turning point in history. We still have time to put an end to the negative effects of climate change, but this requires unprecedented efforts from all walks of life" [UN: 2019] That is, according to the Secretary-General of the United Nations, addressing global climate change is the area of competence of all stakeholders, which can include states, governments, international organizations, corporations, public movements, the scientific community, individuals, the media, etc. This idea is supported by the 2007 Nobel Peace Prize laureate, former Head of the Intergovernmental Panel on Climate Change (2002 to 2015), Rajendra K. Pachauri, who states that "the most driving force behind the implementation of adaptation and mitigation climate change programs are governments and political parties, the UN, international organizations, corporations and every citizen of the planet" [Буняк: 2017]. Particularly important role in overcoming global climate change, Pachauri pays to civil society institutions, in particular public movements and associations, public initiatives of celebrities and the activities of individuals.

Recent literature review. Studies of the risks of global climate change and the role of civil society structures in overcoming them are reflected, in particular, in international documents (UN Framework Convention on Climate Change (UNFCCC), Kyoto Protocol, Paris Agreement), materials from UN conferences (UNFCCC)), official publications of the UN specialized agencies (Evaluation reports of the Intergovernmental Panel on Climate Change, UN Climate Change Reports, World Meteorological Organization Research, Global Atmospheric Service, etc.), publications by other UN agencies (including Food and Agriculture Organization, World Food Program, United Nations High Commissioner for Refugees, International Organization for Migration, UN Intergovernmental Commission on Oceanography, UN Environmental Programme), open materials of national meteorological and hydrological services, regional climate centers, international agreements.

The most extensive publications on this issue are presented in the work of the Intergovernmental Panel on Climate Change under the leadership of R. Pachauri and, in particular, British researchers M. Allen, J. Brum, German V. Kramer, O. Edenhofer, J. Marotzke, and American L. Clarke, K. Field, K. Mach, M. Mastrandrea, B. Preston, Norwegian J. Fuglstwedt, K. 
Oberin, Australian M. Hofden, S. Power, Russian V. Kattsov and others. These studies look at global causes and possible scenarios for managing global climate change.

Specific areas for tackling global climate change, including contribution of civil society and research centers are contained in the work of the Spanish researcher X.K. Abanades, Japanese M. Akai, American S. Benson, K. Keldeira, R. Doctor, Dutch H. De Koninko, B. Metz, L. Meyer, British P. Freund, D. Gale, E. Palmer and others; the role sub-national actors are in the work of Hsu, A.; Widerberg, O.; Weinfurter, A.; Chan, S.; Roelfsema, M.; Lütkehermöller, K. and Bakhtiari, F.

Also information about the role of civil society communication in addressing global climate challenges is also provided in the specialized communication programs and researches on climate change at Yale University, George Mason University, the Adam Corner British Project and the Adelphi Platform. These documents identify the interplay between global climate and non-climate risk factors and the role of international organizations, sub-national actors and research centers in overcoming them.

However, the new realities of global climate change and the impact of international actors require further exploration of this issue. Unfortunately, the role of civil society in the development of global climate change policy and its communicative support has not yet been given sufficient attention in Ukrainian and foreign literature. Therefore, the study of these issues is an urgent problem of modern international communication, and their solution will be of considerable practical importance.

The purpose of the article is to identify the contribution of civil society institutions as new actors of international relations in addressing global climate change and to characterize their role in managing global climate change.

Methods. This scientific intelligence not only emphasizes the need to address the current problem of climate change, but also points to some important trends related to the formation of appropriate climate behavior in the conscious part of humanity. The predictive component of this work is, at least, that in the context of managing the effects of global climate change, the role of the civil society institute is outlined, its prospects and place in enhancing the adaptive capacity of society are defined. To address this range of challenges, the authors have used a number of methods, including systematic analysis, which has provided an insight into the elements of civil society represented by civic organizations and movements, celebrities, and individuals acting as generators of new climate change coping strategies. Dialectics, synergetics, and case-study methods used in the work have made it possible to explore the development of environmental initiatives by civil society institutions and individuals who are able to raise local proposals and ideas internationally.

Main research results. Let us analyze the activities of individual civil society institutions, namely public movements and organizations, projects initiated by celebrities and individuals to address global climate change.

Civil movements. International and national grassroots movements and organizations help promote ideas of responsible climate behavior. One of such project is the international alliance Zero Waste International, which promotes the concept of "no waste", the main idea of which is to reduce the amount of garbage produced through the use of reusable items and things, just as they would be used in nature. By its own definition, "Zero Waste is a moral, economical, effective and global goal aimed at changing people's lifestyles and creating sustainable natural cycles where all surplus materials can become resources, not garbage" [ZWIA: n.d.]. In addition, the Alliance fights for the reduction of hazardous waste and opposes their incineration or disposal. From a global perspective, the Zero Waste concept should help eliminate harmful emissions of soil, water or air, damaging the planet, as well as human, animal and plant health.

The term "zero waste" was first used publicly on behalf of Zero Waste Systems Inc. (ZWS) in the mid-1970s in Oakland, California. ZWS's mission was to find use for the most of the chemical waste generated by the growing electronics industry. Subsequently, they saw an interest in the initiative and began to accept laboratory chemicals for free, which they resold to experimenters, scientists and companies. ZWS also collected all used engine oils, filtered them and sold them to oil 
companies. The movement received recognition and distribution in 1998-2002. Today it continues to grow, with offices in the US, the European Union, Russia, Ukraine, Brazil, Argentina, Puerto Rico, Mexico and other countries. The main benefits of the movement are not only the philosophy of smart consumption, but also financial savings, because according to the organization, following the concept of "zero waste" can save up to $40 \%$ of the family budget.

In Ukraine, the idea of "zero waste" is being promoted, in particular, by the organization "Ukraine without garbage". As part of their educational projects, interactive lectures are held for teachers, students, listeners of international and Ukrainian companies, ordinary residents and other interested and indifferent categories of the population. Successful has been the experience of introducing public sorting stations "NO WASTE recycling station" and eco-friendly social goods store "NO WASTE shop", own brands like \#nonplasticbags. In addition, as stated on the website of the project "Ukraine without garbage", "we strategically cooperate with the Ministry of Ecology and Natural Resources, administrations and municipal enterprises of cities; provide expert evaluation of existing waste management issues to the leading Ukrainian media; we conduct surveys at festivals,

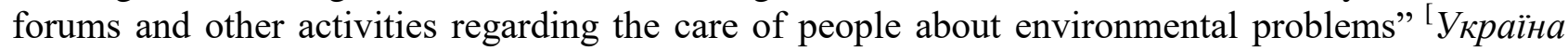
без сміття: 2018].

The ideas of "Ukraine without garbage" are supported by other organizations. For example, the Klitschko Foundation, together with a partner of the Coca-Cola Foundation and Coca-Cola, have launched an educational project called "Zero Waste School", which aims "to introduce a waste sorting culture among schoolchildren and teachers in their school, community, and later in the world" [ZeroWasteSchool: 2019]. As of August 1, 2018, 50 Ukrainian schools, over 12,000 students, parents and teachers became participants of the project; 212 garbage cans were installed; 33 tonnes of recyclables (paper, metal, plastic, batteries, glass) were collected [ZeroWasteDay: 2019]. In 2019, the implementation of this project was continued.

Interesting experience of the environmental project is "Green Library Movement", which has been developing in libraries around the world for 20 years and is associated with the involvement of libraries in protecting the environment. Green Libraries offers ecology-related services, literature and electronic resources, demonstrating the social role and responsibility of libraries as environmental education leaders. In Ukraine, the Children's Library in Priory was the first to join this project. According to project manager Anna Kobets, "we have created a unique ecological space in the library that will provide theoretical and applied information on environmental topics for children and their parents" [Зелена бібліотека: 2018].

The goal of the project is to convince everyone of the necessity to follow the basic rules of environmental management in everyday life, in nature, in the workplace. The main focus is the upbringing of children, the formation of appropriate aesthetic flavors in order for them to understand and be able to see the beauty of the environment, were able to save and protect nature. All this will contribute to the formation of ecological culture, without which the future may not be. The new space will include: creative eco-design (natural colors, natural materials); elements of decor made of recycled materials (recyclables); a selection of books and electronic media on environmental topics and the outside world; thematic program (lectures and master classes on environmental topics, sorting of garbage and recycling, ecoclub, etc.). What has already been done? The library is actively working on completing the thematic program, nature and environmental events are held weekly, partnerships with environmental initiatives and activists are established. Creative design of the ecological space was developed. Due to philanthropists and publishing partners, books on environmental topics have been purchased.

Zero Waste Life has been gaining popularity lately among the members of the Green Library. Its main purpose is to minimize waste arising from production processes and humangenerated household waste. The movement's strategy is to abandon consumer lifestyles and to establish a closed cycle of resource use that will not result in the waste being dumped into landfills but receiving new life in the form of recycled raw materials. For example, at the household level, we are talking about the rejection of disposable products (plastic bags, plastic tableware, durable clothing, etc.), responsibility for the further processing of human-generated waste and the 
prolongation of the life of the things it uses. This project has become a model for the introduction of Green Libraries across the country.

Integrated eco-projects have become a new level of activity of public movements in Ukraine in environmental protection. The International Renaissance Foundation, in the framework of a competition aimed at activating joint initiatives of territorial communities, supported one of the projects of environmental orientation - "Implementation of joint initiatives of communities as a guarantee of social development". The idea of the project was born in the process of active fundraising work for the all-Ukrainian volunteer eco-project "Let's do it, Ukraine: Let's make Ukraine Clean". The Integrated Environmental Initiative was first supported in 2011 by the Krona CF when the AIESEC Ukraine Green Rush project, a new OSCE "Green Pack" project and the AllUkrainian initiative "Let's Do It Ukraine" were combined. The essence of the project was that for 2 months international volunteers of AIESEC conducted ecological lessons on the methodical basis "Green Pack" and announced all-Ukrainian cleaning in secondary schools of Ukraine, while providing organizational assistance to the regional coordinators "Let's Make Ukraine Clean". It has been found that the biggest environmental problems of the urban communities of Ukraine are the lack of properly equipped and sanctioned garbage disposal sites and the creation of new landfills in a geometric progression.

The results of the cooperation were very positive, the number of partners expanded, the local authorities were involved. In the first stage (working with local authorities) the main goal was to solve key environmental issues - garbage collection in the region, technical equipment, disposal, sanitary landfills, etc. To address this challenge, a series of social surveys and polls were conducted, attracting the maximum number of interested and active residents (entrepreneurs, public figures, authorities), identified and discussed the most problematic issues. With the participation of the authorities, roundtables / public hearings and other public events on environmental issues were held. In accordance with the results of the event, proposals were formulated and submitted to local authorities.

The aim of the second stage (implementation of the Green Package OSCE eco-lesson system) was to educate eco-awareness among young people and the local population. For this purpose, environmental lessons and trainings were conducted in schools with the involvement of volunteers. It is gratifying to note that school teachers often supported the initiative and independently conducted thematic classes. With the expansion of the target audience implementation of environmental initiatives aimed at raising environmental awareness among the population, there were many problems with the involvement of locals in the actions to clean the green areas, landfills. An important effect was recorded: after 2 such clean-ups, residents not only stopped throwing garbage in the nearby ravines, but quickly began to be interested in the activities of the authorities in this area and the possibility of effective solution of eco-problems in the region. This means that an integrated approach to solving environmental problems not only solves environmental problems, but also nurtures a European-level ecological culture in any region, city and village of Ukraine.

Today, Ukraine allocates much less funds for the development of eco-projects than is a real need. Accordingly, members of public movements are beginning to seek help from global companies, which are often willing to invest in interesting ideas from civil society. The issue of investments in ecology in recent years has become urgent. Thus, in February of this year, the Verkhovna Rada of Ukraine ratified an agreement between the Cabinet of Ministers and the Government of Germany on financial cooperation. Ukraine will soon be able to receive a grant of up to 14 million euros for the implementation of the project "Support to nature reserves in Ukraine". The explanatory note emphasizes that this "project is aimed at building infrastructure facilities in nature conservation areas, developing a management system based on local community involvement, preserving biodiversity based on sustainable regional development" [Доскіч: 2016].

A step-by-step approach is planned to be pursued. It will initially include two nature conservation areas in the Carpathians (Gorgany Nature Reserve and Carpathian Biosphere Reserve). Further objects for the project implementation will be added during its implementation. It is stated 
that they should be selected mainly from the short list defined in the Feasibility Study of the project and meet the criteria that were applied in the shortlisting (first of all, the level of biodiversity conservation, project implementation potential). However, the agreement stipulates that the project "Support to nature reserves in Ukraine" by mutual agreement between the governments of the two countries may be replaced by other projects.

Today, Ukraine doesn't have a large number of programs aimed at developing the environment. One of the successful is "Let's build ECO Ukraine together". It exists in the form of a competition that anyone can join by registering their environmental project in the program. After voting for all projects submitted to the program, the winner receives a certain amount for its reproduction. The ECO projects are implemented by the International Charitable Foundation "Ukrainian Charity Exchange". The winners are chosen by both qualified jury members and Ukrainians themselves, who are able to vote online. Another all-Ukrainian environmental competition is the ECONATION grant. It was created with the assistance of the Ministry of Ecology and the International Charitable Foundation Konstantin Kondakov. The project aims to change the ecological situation on the planet and promote the scientific potential of young scientists in the field of nature and environmental activities. The project addresses both urgent environmental issues and support for innovation. With the assistance of the authorities, for 15 years there has been an all-Ukrainian environmental competition "To Clean Sources". It has been held annually since 2001 and aims to engage the general public in practical environmental work. First of all, it is about protection and improvement of the state of springs, rivers and reservoirs of Ukraine, rational use of water resources, raising of environmental and legal awareness of Ukrainians.

Georgia harbors the largest and most active movements and non-governmental actors working on global climate change and its mitigation in the South Caucasus region. Caucasus Environmental NGO Network (CENN) is the biggest of them covering all three countries of the region (i.e. Armenia, Azerbaijan, Georgia) and specializing, apart from others, in areas of sustainable management of resources and combating climate change. It is one of the most influential civil society actors in the field because it can steer the climate change and mitigation discussions via using its vast environmental research and policy expertise. It closely partners with governments, other non-governmental and international organizations as well as various societal groups and individuals to promote environmental-friendly and climate-smart ideas and action. Its two programs (one on Climate Change \& Disaster Risk Reduction, and the other on Rural Development \& Climate Smart Agriculture) are seminal in its efforts to foster relevant structural reforms and raise awareness on these issues. However, CENN's expertise goes beyond these two areas and covers everything from resources management to green economy to gender and environment to compliance management, and others.

CENN is valuable for its energetic public awareness raising campaigns too. It has four major footprints in this regard. First, Green Office campaign urges the office holders and workers to reconsider their working behavior by making more sustainable actions and implement green initiatives in the workplace. It also offers green office checklist and recommendations on all relevant issues from paper management to waste recycling to energy saving to bonus system for carpooling/public transportation. Its slogan "Make An Impact While Working" speaks itself on the essence of the campaign. Second, new legislation introduced a total ban on the use of plastic bags in Georgia. Therefore, the Green Bag campaign aims at discovering the alternatives and using the CENN-produced green bags. Third, CENN initiated a famous and large-scale environmental campaign - Keep Georgia Beautiful, oriented on cleaning littered areas. It is funded by US Agency for International Aid and has its hashtag \#KeepGeorgiaBeautiful. Its success is very much intertwined with the engagement of actors of the private, public and civil society sectors. The program assists "the Government of Georgia to modernize the country's waste management sector and support sustainable and inclusive economic development. The program supports responsible natural resources management to minimize adverse impacts on human health and natural resources" [CENN: 2020]. And fourth, CENN manages a vast electronic library with open access, with slogan "Green Reading". 
CENN's wide network, high level of professionals and its close cooperation with important stakeholders (such as governmental bodies, European Union, USAID, National Geographic, academic institutions, Forest Group, etc.) ensure the quality results and are the main source of the organization's high reputation.

Nevertheless, CENN is not the only organization on this challenging road. There are several other groups who are actively engaged in the process. This includes non-governmental organizations (e.g. Black Sea NGO Network, Green Alternative, Caucasus Nature Fund), local branches of international environmental organizations (e.g. Friends of the Earth Georgia), major international organizations (e.g. European Union, United Nations, World Bank), international and local foundations and donors (e.g. Heinrich Boell Foundation, German Society for International Cooperation [GIZ], Bank of Georgia), and foreign governments/diplomatic institutions (e.g. Embassy of France, German Federal Ministry for the Environment, Nature Conservation, Building and Nuclear Safety).

Therefore, the role of public movements as participants in the process of overcoming global climate challenges is that they, as representatives of civil society, have the opportunity to identify the problem and raise it from the bottom up. Practice has also shown that positive results using an integrated and phased approach can be obtained in partnership with "NGOs - authorities". The "think globally - act locally" principle exemplifies the philosophy of NGOs to address global climate challenges.

Celebrities. Since the mid-2000s, famous people (or celebrities), actors, singers, and athletes have begun to play an increasing role in informing the public about certain aspects of climate change, in addition to environmental experts and politicians. Some have relevant social media pages or fan groups with millions of supporters and subscribers, others provide financial support for environmental initiatives, participate in information campaigns, make films on global climate change, speak at UN climate conferences, and inspire people be more environmentally conscious. Climate-oriented activity of celebrity helps to bring this problem to a wide and socially active audience.

A study by the British Greenmatch Project identified 10 global celebrities who invest most in environmental projects and use their prominence to raise awareness of the international community about climate change and ways to help save the planet. The Greenmatch list includes Leonardo DiCaprio, Brad Pitt, Matt Damon, Kate Blanchett, Don Cheadle, Cameron Diaz, Emma Watson, Farrell Williams, Natalie Portman and Justin Timberlake [GreenMatch: 2016].

The Leonardo DiCaprio Foundation was established in 1998 to "support projects around the world that create climate resilience, protect vulnerable wildlife and restore balance between threatened ecosystems and communities" [Leonardo DiCaprio foundation: n.d.]. To date, the fund has funded more than $\$ 80$ million in projects in 50 countries around the world, from preserving mangrove forests to supporting indigenous peoples and nationalities. In 2016, a wide-ranging resonance (and the Audience Award at the Toronto International Film Festival) received Mark Monroe's documentary "Before the Flood" starring Leonardo DiCaprio. He talks about climate change caused by human activity and how humans can try to prevent the death and extinction of species and natural ecosystems on the planet. The world-famous actor, Oscar winner, Honorary Ambassador of the United Nations is the central figure in the film's plot. As he travels the planet, in his own experience, he is convinced that the problem of global warming really exists, and that it is serious enough not to pay attention to it. Using his privileges and social status, DiCaprio meets with community activists, scholars, and the most influential people on the planet, including Barack Obama, Ilon Musk, and His Holiness Pope Francis.

The Make it Right Foundation, founded by Brad Pitt, has built 150 green energy-efficient homes for victims of Hurricane Katrina. Matt Damon has launched a charity project, water.org, to help bring clean water to African citizens. Kate Blanchett is a supporter of sustainable development ideas and is working with SolarAid, a charitable foundation that seeks to minimize and subsequently stop the use of kerosene lamps in Africa by 2020. Together with her husband Andrew Epton, Kate Blanchett has funded the installation of two thousand solar panels on the roof of the 
Sydney Opera House. Emma Watson supports People Tree organic products, all of which are made of organic fabrics and materials that can be safely disposed of. Natalie Portman, who promotes a vegan, non-violent lifestyle, is the recipient of the EMA (Environmental Media Awards) for her continued support of environmental issues and her continued support of ethics for animals and wildlife. She is also a designer of vegan shoes. The EMA's Climate Change Contribution Award winner is Justin Timberlake.

It can be also argued that the role played by celebrities as actors of addressing climate change challenge is the result of a political environment increasingly influenced by public relations and the media, reflecting particular political ideas, policies and attitudes. Celebrities act as representatives of a segmented mass audience operating in the centers of elite political power. At the same time celebrities present environmental concerns to their audiences; that is, they actualize the feelings of their audience on the political scene. It is in this context that celebrities have gained their prestige as political, social and environmental "experts", and celebrity's political appearances provide important ways to engage voters and viewers in climate change action.

Other climate celebrity initiatives can be cited. Thus, in 2010, Ben Affleck, together with Whitney Williams, founded the Eastern Congo Initiative, which became "the first American grantmaking initiative entirely focused on working with and for the people of the Eastern Congo" [ECI: 2010]. They have partnered with several Congolese NGOs to increase agricultural productivity and improve the lives of small farmers - from coffee farmers in the eastern part of the country to sustainable cocoa producers seeking to create ethical production facilities and infrastructure to supply such international ethical buyers as Lush Cosmetics. Actor Channing Tatum collaborates with PlantMed, an organization that takes care of the indigenous peoples of the Amazon, the world's epicenter for medicinal plants and seeks to address the rapid threat of the destruction of tropical forests and indigenous knowledge of plant and botanical medicine [PlantMed: n.d.]. The Hilaria \& Alec Baldwin Foundation (co-founded by Alec Bolwin) has been providing grants in New York and Long Island since 2006 to support Central Park and charitable initiatives such as supporting yoga lessons in New York City public schools.

Ukrainian celebrities are also holding actions to address global climate challenges. Wellknown magazine Marieclaire lists the cases of designer Xenia Schneider, musician Ivan Dorn and band Onuka [Зализниикая: 2018]. Yes, Ukrainian designer Xenia Schneider has launched a action "Clean Challenge UA", which could be attended by anyone from August 1 to August 8, 2019. For this purpose it was necessary to make a photo in a place where there is a garbage, to remove it and again to be photographed, but against the background of pure nature. Then send the pictures to the brand mail and post to your account with the hashtag \#cleanchallengeua. Promotions to participate in the action were gifts from the Ksenia Schnaider brand: T-shirts, organic linen, vegan desserts and handmade cosmetics. Musician Ivan Dorn in a series of videos titled "About Me - About Her About Us" read the text of the eco-manifesto and urged people to unite to save nature, and warned that the planet could very soon be like a city-the ghost of Pripyat, which suffered the most from the Chernobyl accident. The artist himself says that he began to think seriously about environmental problems a year ago when he introduced hiking into his practice. The clip of the popular Ukrainian group Onuka, nominated for the prestigious Social World Film Festival Award, tells about the problem of garbage in Ukraine and created within the framework of Ecostrum initiative with the organization "Ukraine without garbage". For clarity, the video was filmed at a dump near Kiev to show the problem on a full scale. Another popular singer, Nata Zhizhchenko many years ago, abandoned genuine leather and fur and, together with her husband, Yevgeny Filatov, began to consciously approach garbage sorting. All money from the clip were directed to support "Ukraine Without Trash" organisation.

Thus, the special role of celebrity as an actor in overcoming global climate change lies in the fact that they have the resources to support charitable organizations and the ability to influence the public, offer new climate actions that go beyond classical scientific approaches and foster more emotional and intuitive connections between their audiences and climate change in their daily lives. Contemporary celebrities are thus working to shape how audiences and citizens should feel about 
climate change, trying to get them to act or change their behavior. On the one hand, celebrity, acting as "emotional witnesses", can draw attention to the problem of global climate change, but on the other, they increase the value of their brand by joining an acute global problem. Climate change activism is often transformed into a spectacle, thus stimulating the audience with the necessary emotions and actions to address global environmental change. Some researchers also see a political implication in the climate activity of celebrity.

Individual citizens. Nobel Peace Prize laureate Rajendra Pachauri believes that the newest actors that can leverage global climate change issues may be individual citizens, and states: "we need to change our lifestyles... a lot of unnecessary things happen in a consumer society... it would be good to review our eating habits as well: you need to stop eating so much meat, in which case you will be healthier and the planet" [Сметанская: 2017]. A well-known scientist assigns a separate role to the youth, who must draw up a "road map for change, that is, each young person must calculate his or her own carbon footprint and think about how to reduce it." [Сметанская: 2017]

The World Wildlife Fund (WWF) has developed and issued a leaflet on how each individual can contribute in mitigating global climate change. They offer a range of activities that people can do in the bathroom, on the go, in the store, at the office, or on vacation. These recommendations can be read on the organization's website at: https://wwf.ru/upload/iblock/461/eco_tips_wwf.pdf. Among the simplest ways are the following: "in the house to timely adjust the flowing taps, install an economical shower nozzle; on the road, try to use your car or plane less often. But if you can not do without an aircraft, it is recommended to fly direct flights, since the largest amount of fuel is consumed during takeoff. To buy only the food that is needed, since one third of all food in the world is thrown away, and to reduce the consumption of meat, because its production requires a large amount of resources - water, energy, feed. In the office it is possible and necessary to reduce energy consumption and volume of waste, to print only the necessary and on both sides of the sheet, etc." [WWF: 2003].

The initiators of the "Open School of Sustainable Development" agree that one of the first steps in fulfilling the UN's thirteenth sustainable development goal to tackle global climate change is conscious steps of every planet citizen [\#ЗнайСвоиЦели: n.d.]. Their recommendations are in line with the recommendations of the World Wildlife Fund and emphasize that changes in the world begin with changes in the creed and behavior of each individual.

Thus, initiative citizens as representatives of civil society are an important component of attracting attention and addressing global climate challenges, as they know their country much better than the government. Given the large size of this category, interest and criticality, citizens have the opportunity to achieve greater success than government organizations. Therefore, the participation of citizens as representatives of civil society is a significant factor in the formation of an effective system of adaptation to global climate challenges.

Conclusions. Thus, the adaptation of humanity to global climate change is now regarded as a necessity for solving technical, managerial and communication problems. Managing Global Climate Projects involves interaction between many international actors and addresses global climate challenges. Today, there is a strong understanding of the important role of civil society institutions in managing climate challenges.

Civil society, represented by grassroots organizations and movements, celebrities and individuals, act as incubators and accelerators of new strategies for addressing climate challenges. Own projects of NGOs and movements, celebrities and individuals are increasingly becoming the platform for the demonstration, testing and dissemination of new, cutting-edge climate adaptation technologies. In other words, civil society is a group of people with a common interest who, on the one hand, play a positive role in a democratic and pluralistic society, defining the principles and style of climate policies of national governments, and on the other, affecting the activities, hopes, and beliefs of society. Civil society is also a source of information on global climate change, how to adapt and mitigate, and the role of the individual in the issue. 
When considered by NGOs, they have the opportunity to raise local proposals and ideas to an international level. The activities and climate projects of celebrities and individual citizens are advisory and informative and affect a segmented audience. These projects are funded by their own funds, donations, contributions and implemented through the creation of special funds, raising public awareness of climate challenges through social networks, holding promotions, attracting other thought leaders and personalities, participation in forums, conferences, discussions on global climate challenges and the dissemination of educational literature. Due to small management structures, the climate projects of these actors are realized much faster than the states and international organizations.

\section{Referrncies}

1. \#ЗнайСвоиЦели (n.d.). Official web-site. Что можете сделать вы? [What can you do?]. Available at: 〈http://sdg.openshkola.org/goal13>.

2. CENN (2020). Keep Georgia Beautiful. Available at: <http://www.cenn.org/ongoingcampaigns/keep-georgia-beautiful/ >

3. ECI (2010). Eastern Congo Initiative. Official web-site. Available at: $<$ http://www.easterncongo.org/about>

4. GreenMatch (2016) 10 Influential Celebrities Making a Difference in Saving the Planet. Available at: <https://www.greenmatch.co.uk/blog/2016/10/celebrities-making-a-differencein-saving-the-planet>

5. Leonardo DiCaprio foundation.(n.d.) Official web-site. Available at: <https://www.leonardodicaprio.org/about/>

6. PlantMed (n.d.) Amazonian Medicine as a disruptive technology. Available at: <https://www.plantmed.org/>

7. UN (2019). UN Climate Action Summit 2019. Available at: <https://www.un.org/en/climatechange/un-climate-summit-2019.shtml>

8. WWF (2003). С чего начать спасение планеты: простые советы от WWF [How to start saving the planet: simple tips from WWF]. Available at: <https://wwf.ru/upload/iblock/461/eco_tips_wwf.pdf>

9. Zero Waste School (2019). Available at: <http://www.klitschkofoundation.org/projects/education/zero-waste-school/>.

10. ZeroWasteDay (2019) 50 шкіл-учасниць проекту Zero Waste School готуються до Zero Waste Day [50 participant-schools of ZeroWasteSchool Project are preparing for Zero Waste Day]. Available at: <https://www.coca-colaukraine.com/stories/ZWDSeptember>

11. ZWIA (n.d.) Zero Waste Definition. Available at: http://zwia.org/zero-waste-definition/

12. Буняк P. (2017) Нобелевский лауреат: чтобы спасти Землю нужно отказаться от мяса, авто и одежды [Nobel laureate: In order to save the Earth we need to refuse meet, cars and clothes], Facty, 11: 7.

13. Доскіч В. (2016) еко-проекти в Україні: міжнародна допомога [Eco-projects in Ukraine: international support], UNIAN, 70: 2-3

14. Зализницкая О. (2018) От Ивана Дорна до леонардо ДиКаприо: как украинские и мировые знаменитости поддерживают эко-движение [From Ivan Dorn to Leonardo DiCaprio: how Ukrainian and world celebrities support eco-movements], Marie Claire, 11: 17-29.

15. Зелена бібліотека (2018) Чи може бути бібліотека лідером екологічної освіти? [Can a library be a leader of eco-education?]. Available at: http://livelibrary.com.ua/green-library/

16. Сметанская О. (2017) Раджендра Пачаури: "Из своей Нобелевской премии на себя я не потратил ни цента" [Rajendra Pachauri: I have not spent any cent for myself form my Nobel Prize], Факти, 147: 3-4.

17. Україна без сміття (2018) [Ukraine without waste]. Official FB-page. Available at: $<$ https://www.facebook.com/NowasteUkraine/> 